\title{
Comparison of clinical outcomes between femtosecond laser-assisted versus conventional phacoemulsification
}

\author{
Robert Edward Ty Ang ${ }^{1,2^{*}}$, Michelle Marie Salcedo Quinto², Emerson Marquez Cruz', Mark Christian Reyes Rivera ${ }^{1}$
} and Gladness Henna Austria Martinez ${ }^{2}$

\begin{abstract}
Background: To compare femtosecond laser-assisted versus conventional phacoemulsification in terms of visual and refractive outcomes, cumulative dissipated energy, anterior chamber inflammation and endothelial cell loss.

Methods: In this retrospective cohort study, records of eyes that underwent femtosecond laser-assisted cataract surgery (FLACS) or conventional phacoemulsification (CP) were reviewed. The Victus femtosecond laser (Bausch and Lomb, Germany) was used to carry out corneal incisions, anterior capsulotomy, and lens fragmentation in FLACS procedures. Manifest refraction spherical equivalence (MRSE), uncorrected distance visual acuity (UDVA), corrected distance visual acuity (CDVA), cumulative dissipated energy (CDE), postoperative cells and flare and endothelial cell count data were collected. Subgroup analysis of the visual acuity tests was performed based on the type of intraocular lens implanted (monofocal, monofocal toric, multifocal, multifocal toric, accommodating).

Results: A total of 735 eyes were included in the study (296 eyes for the FLACS group and 439 eyes for the CP group). At one year follow-up, 120 eyes comprised the FLACS group and 265 eyes for the CP group. MRSE in the FLACS group was $-0.16 \pm 0.58 \mathrm{D}$ and $-0.20 \pm 0.52 \mathrm{D}$ in the CP group $(P=0.50)$. UDVA in the FLACS group was $20 / 25$ (mean logMAR $0.12 \pm 0.13$ ) and 20/25 (mean logMAR $0.11 \pm 0.13$ ) in the CP group $(P=0.48$ ). CDVA was 20/20 (mean $\log M A R 0.03 \pm 0.07$ ) in the FLACS group and $20 / 20$ (mean logMAR $0.02 \pm 0.06$ ) in the CP group $(P=0.15)$. No statistically significant trend was seen for FLACS versus CP by intraocular type for visual acuity. CDE for the different cataract grades ranged from $6.97 \pm 5.74$ to $29.02 \pm 16.07$ in the FLACS group and $7.59 \pm 6.42$ to $35.69 \pm 18.30$ in the CP group. The FLACS group was significantly lower for post-operative central corneal edema $(P=0.05)$, cells and flare $(P=0.01)$, and endothelial cell loss $(P=0.04)$.

Conclusions: Femtosecond laser-assisted cataract surgery and conventional phacoemulsification had similar refractive and visual outcomes. Phacoemulsification energy, anterior chamber inflammation and corneal endothelial cell loss were less in the femtosecond laser group.
\end{abstract}

Keywords: Femtosecond laser, Phacoemulsification, Cataract, Cumulative dissipated energy, Endothelial cell loss, Flare

\footnotetext{
* Correspondence: rtang@asianeyeinstitute.com

'Asian Eye Institute, Rockwell Center, Makati City 1200, Philippines

${ }^{2}$ Cardinal Santos Medical Center, 10 Wilson St., San Juan City 1502,

Philippines
}

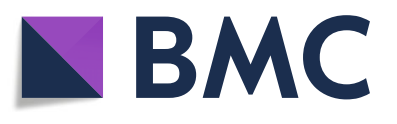

(c) The Author(s). 2018 Open Access This article is distributed under the terms of the Creative Commons Attribution 4.0 International License (http://creativecommons.org/licenses/by/4.0/), which permits unrestricted use, distribution, and reproduction in any medium, provided you give appropriate credit to the original author(s) and the source, provide a link to the Creative Commons license, and indicate if changes were made. The Creative Commons Public Domain Dedication waiver (http://creativecommons.org/publicdomain/zero/1.0/) applies to the data made available in this article, unless otherwise stated. 


\section{Background}

The most commonly performed ophthalmologic procedure in the world is cataract surgery, with approximately 20 million surgeries done in 2010 and estimated to reach 32 million by 2020 [1]. Phacoemulsification is the current preferred method of removing cataracts wherein the lens material of the cataract is softened using ultrasonic energy (emulsify) followed by extraction from the eye through irrigation and suction [2]. Specific steps in conventional cataract surgery through phacoemulsification include creating corneal incisions using a blade or keratome, manually opening the anterior capsule (capsulotomy) using a forceps or bent needle, fragmenting the cataractous lens with ultrasonic energy and chopper instruments, suction of lens material, implantation of an intraocular lens (IOL) and finally aspiration and cleanup of viscoelastic and retained lens cortical fragments [2]. In recent years, the femtosecond laser has been utilized to perform the vital steps of corneal incision, anterior capsulotomy and lens fragmentation [2].

A femtosecond laser is an infrared laser that works by photodisruption wherein laser energy absorbed by the tissue induces rapid expansion, creating microcavitation bubbles and acoustic shock waves that cause morphological changes [3]. It acts like a cutting tool by firing thousands of bubbles side by side thereby creating a plane of dissection. The near infrared wavelength of $1053 \mathrm{~nm}$ is not absorbed by optically clear tissues such as the cornea and affect only the tissue at the focus point of the beam [3]. The reduced pulse duration in the femtosecond range $\left(10^{-15} \mathrm{~s}\right)$ compared with Nd:YAG $\left(10^{-9} \mathrm{~s}\right)$ means significant reduction of collateral tissue damage $[2,3]$.

Femtosecond laser technology has been initially introduced as a bladeless option of corneal flap creation in laser in situ keratomileusis (LASIK) [4, 5]. The predictability, accuracy and lower frequency of complications in corneal flap creation afforded by femtosecond lasers and the introduction of premium IOLs paved the way of incorporating this type of laser to 'pre-treat' cataractous eyes to produce more precise and reproducible clear corneal incisions and capsulotomies and placement of lens softening patterns prior to phacoemulsification [6]. It was postulated that since the femtosecond laser can do a perfect, round-shaped, smaller capsulorhexis, it can hold the lens better and prevent intraocular lens rotation, tilting, and decentration. This may prove advantageous more so for multifocal, toric or accommodating intraocular lenses [7]. Currently, four commercial femtosecond laser-assisted cataract surgery platforms are available: LenSx (Alcon, USA), Catalys (AMO, USA), LensAR (Lensar, USA), Victus (Bausch and Lomb, Germany) and Femto LDV 28 (Ziemer, Switzerland). These platforms vary slightly in their docking system and imaging modality, but the overall procedure performed is similar.

Studies have shown that femtosecond laser-assisted cataract surgery (FLACS) produce better clear corneal incision morphology [8], more precise and reproducible capsulotomies [9-13], better IOL centration [11], better predictability of IOL power calculation [12, 13], significant reduction in effective phacoemulsification time [9, 14-16], reduced ultrasound power and ultrasound time [16], less post-operative anterior segment inflammation [17], significant reduction in early post-operative corneal edema [18], decreased central endothelial cell loss [18, 19 ], and faster visual recovery and earlier stabilization of refraction [13]. Even with these reported benefits, issues of additional learning curve [20-22] for surgeons and costs [23] have prevented surgeons and eye centers worldwide from fully converting to FLACS. Adverse effects associated with femtosecond laser-assisted cataract surgery that have likewise hindered universal adaption include endothelial cell loss for laser-automated corneal incisions [18], capsulotomy margin irregularity [23, 24], anterior capsule tears [10, 25-28], miosis [29, 30], increase in intraocular pressure [31-33], and cystoid macular edema [34].

Additional studies on femtosecond laser-assisted cataract surgery need to be performed to determine the impact of femtosecond lasers on patient outcomes and quality of cataract surgery. In this study, we analyzed patients from a single center who underwent either FLACS or conventional phacoemulsification $(\mathrm{CP})$ and compared their visual and refractive outcomes, cumulative dissipated energy, anterior chamber inflammation and endothelial cell loss.

\section{Methods \\ Patients}

This observational retrospective cohort study reviewed 735 patient records of FLACS and CP cases performed by a single surgeon at the Asian Eye Institute from January 2011 to September 2015. Approval by the institutional ethics committee was obtained and the study was performed according to the tenets of the Declaration of Helsinki. All patients 18 years and older with at least 1 month follow-up were included. Advancing age may be linked to more eye diseases, however, the study results should only be attributed to the removal of cataract hence other eye pathologies were excluded. Eyes with corneal scarring, keratoconus, amblyopia, glaucoma, retinal problems, macular pathology, and optic nerve damage were excluded to manage confounders and bias.

\section{Pre-operative assessment}

Each patient had a complete ophthalmologic evaluation, which included anterior segment and dilated posterior 
segment examinations. Uncorrected distance visual acuity (UDVA), uncorrected near visual acuity (UNVA) using Jaegers Chart at 16 in., corrected distance visual acuity (CDVA), distance-corrected near visual acuity (DCNVA) at 16 in., refraction with sphere, cylinder and add, and manifest refraction spherical equivalent were logged. Other parameters noted were cataract grade based on the Lens Opacities Classification System III (LOCS III), average keratometry based on biometry (IOLMaster V.5, Carl Zeiss Meditech Inc., Jena, Germany), type of IOL used (monofocal, monofocal toric, multifocal, multifocal toric, accommodating), and endothelial cell density by specular microscopy (Konan CellChek XL, Konan Medical, Irvine, CA). Eyes were dilated with tropicamide $0.5 \%$, phenylephrine $0.5 \%$ (Mydfrin, Santen, Japan), and ketorolac (Acular, Allergan, USA) 1 drop every 15 min for 3 cycles prior to surgery.

\section{Surgical procedure}

Cataract surgery was performed on all patients under intravenous Midazolam $0.1 \mathrm{mg} / \mathrm{ml}$ and Fentanyl $0.5-1$ $\mathrm{mcg} / \mathrm{kg} /$ dose sedation and topical anesthesia. A 15degree blade was used to create two paracentesis incisions at the 12:00 and 6:00 area, intracameral 75\% lidocaine in fortified Balance Salt Solution (BSS Plus, Alcon, USA) and viscoelastic (Discovisc, Alcon, USA) was injected into the anterior chamber and a temporal clear cornea incision was created using a $2.75 \mathrm{~mm}$ keratome. Continuous curvilinear capsulorhexis was performed manually, followed by phacoemulsification with Infiniti (Alcon, Fort Worth, Texas, USA) using divide and conquer technique, bimanual irrigation and aspiration of cortical remnants, IOL implantation and evacuation of viscoelastic.

Patients who opted for FLACS underwent the laser portion of the procedure first. The Victus (Bausch and Lomb, Germany) femtosecond laser was used to perform anterior capsulotomy, lens fragmentation then corneal incisions (temporal main incision and 2 paracentesis side ports), in that sequence (Fig. 1). A suction ring was first applied, after which a curved patient interface was docked over the cornea without flattening the corneal curvature. A round capsulotomy was created with energy set at $7.5 \mu \mathrm{J}$ (Fig. 2). The spot size was $3 \mu \mathrm{m}$ with spacing of $6 \mu \mathrm{m}$ along the path (Rim spot distance) and $4 \mu \mathrm{m}$ between paths in the vertical cut direction (Rim path distance). The surgeon decided on the diameter of the capsulotomy based on the type of IOL to be used wherein $5.0 \mathrm{~mm}$ was selected when using C-loop lenses and plate haptic lenses (AT Lisa, Carl Zeiss, Germany) or $5.5 \mathrm{~mm}$ when using accommodating lenses with hinged haptics (Crystalens, Bausch and Lomb, USA).

A combined circular (2 circles, diameter of $2.0 \mathrm{~mm}$ and $2.8 \mathrm{~mm}$ ) and 4-cut cross-shaped pattern (diameter of $8.0 \mathrm{~mm}$ ) was used for lens fragmentation with pulse energy at $8.0 \mu \mathrm{J}$ (Fig. 3). A $700 \mu \mathrm{m}$ clearance zone was applied to avoid damaging the anterior and posterior capsule. Femtosecond laser was used to create two paracenteses and a clear corneal incision (Fig. 4). Width of the main port corneal incision was at $2.75 \mathrm{~mm}$ and 1 . $6 \mathrm{~mm}$ for each of the 2 side ports. Main port was positioned at $210^{\circ}$ for the right eye and $30^{\circ}$ for the left eye. Side ports were at $95^{\circ}$ and $275^{\circ}$ for the right eye, and at $100^{\circ}$ and $280^{\circ}$ for the left eye. Femtosecond laser treatment complications such as non-free floating capsulotomies, capsular tears, and suction breaks were tallied.

After treatment with the Victus femtosecond laser, patients were transferred to the operating theater for phacoemulsification (Fig. 5). After sedation, corneal incisions were opened using a designated instrument (Ang Corneal Femtodissector, Storz, USA) (Fig. 6) and the separated anterior capsule was removed with a forcep. All other steps were similar to conventional phacoemulsification.

IOLs used included the following (i) monofocal: Alcon Acrysof IQ, Bausch \& Lomb Akreos Adapt AO, Bausch and Lomb Envista MX60, Zeiss CT Asphina; (ii) monofocal toric: Alcon Acrysof IQ Toric, Bausch \& Lomb Envista MX60 Toric; (iii) multifocal: Alcon Acrysof IQ Restor, FineVision Physiol Trifocal, Oculentis Lentis,

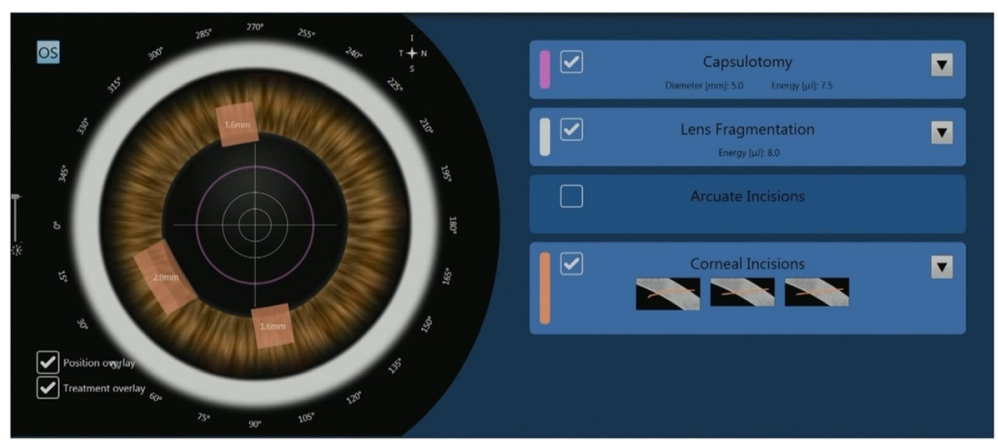

Fig. 1 Femtosecond laser treatment planning for capsulotomy, lens fragmentation and corneal incisions 


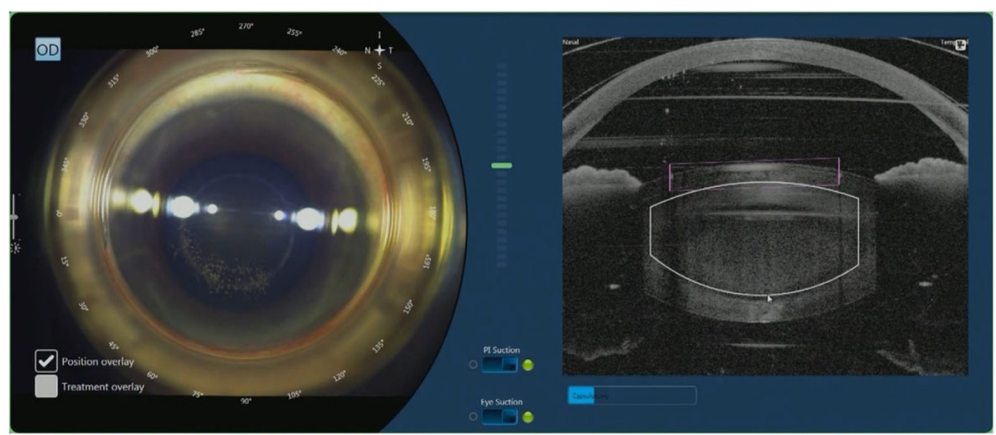

Fig. 2 Femtosecond laser creating an anterior capsulotomy

Zeiss AT Lisa Tri; and (iv) accommodating: Bausch \& Lomb Crystalens. Cumulative dissipated energy displayed on the phacoemulsification machine were logged for both FLACS and CP based on cataract grade. The standardized test of Lens Opacities Classification System III (LOCS III) was used for grading the cataracts to lessen bias. Postoperative antibiotic, steroid and nonsteroidal antiinflammatory drops were given to all patients.

Routine postoperative follow-up data scheduled at 1 day, 1 week, 1 month, 3 months, 6 months, and 1 year were collected. Variables included MRSE, UDVA, and CDVA for all IOLs and per IOL type. UNVA and DCNVA were analyzed for multifocal lenses and accommodating lenses. Central corneal edema, peripheral corneal edema, and aqueous cells and flare grading were recorded at 1 day and 1 week post-operation. Aqueous cells and flare were graded using the standardized test called the Standardization of Uveitis Nomenclature (SUN) Working Group Classification for anterior chamber inflammation to remove bias. Endothelial cell densities were recorded pre-operatively and at 1 month postoperation by specular microscopy (Konan CellChek XL, Konan Medical, Irvine, CA).

\section{Statistical analysis}

Continuous data were summarized by mean \pm standard deviation and categorical data by number (percentage). Comparisons among the FLACS and CP groups were analyzed using t-test for continuous variables with two categories, using a two-sided confidence interval of $95 \%$. Chi-square test was used for an association between variables with more than 2 values. Statistical analyses were

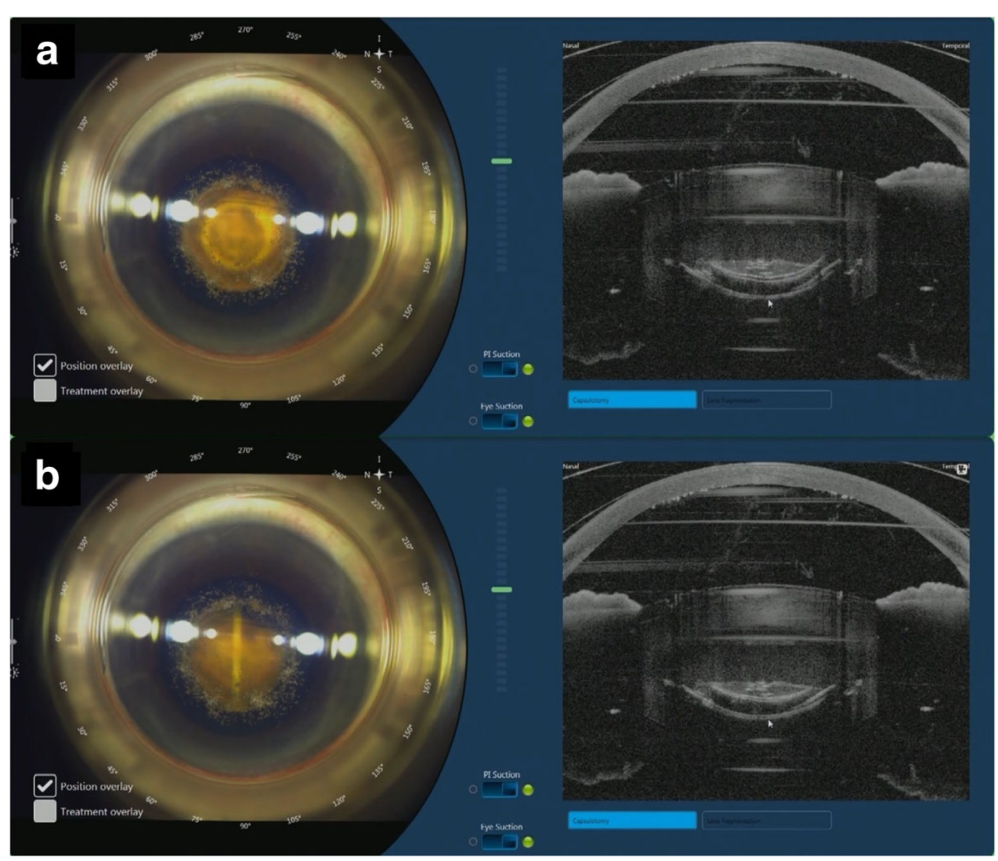

Fig. 3 Femtosecond laser treatment lens fragmentation. a Circular pattern. b Radial pattern 


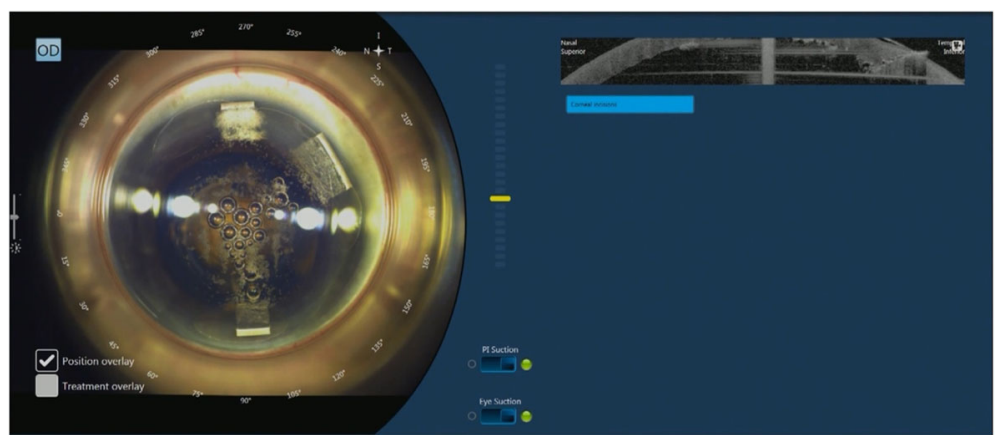

Fig. 4 Femtosecond laser treatment creating a main port and two side port incisions

performed with SPSS 20.0 software (SPSS Inc., Chicago, Illinois). The level of significance was set at $P$ value of less than or equal to 0.05 across all parameters.

\section{Results}

This study evaluated 735 eyes, with 296 in the FLACS group and 439 in the CP group. The FLACS group had a higher age population, worse pre-operative DCNVA, higher pre-operative near vision add, and a higher incidence of grade 4 cataracts. The $\mathrm{CP}$ group had more grade 2 cataracts. The rest of the pre-operative parameters were similar (Table 1). Mean follow-up time for FLACS was 27.31 weeks and for CP, 33.94 weeks.

At the one year post-operative period, 120 eyes comprised the FLACS group and 265 eyes for the CP group. Attrition rate was at $59.46 \%$ for FLACS and $39.64 \%$ for CP. MRSE of the 2 groups were analyzed. Both groups had statistically similar percentages of patients per half diopter range of MRSE (Table 2).

Subgroup analysis was performed based on the type of IOL. All IOLs and their respective subgroups (monofocal, monofocal toric, multifocal, multifocal toric, accommodating) were analyzed for MRSE (Table 3), Mean Refractive Cylinder (Table 4), UDVA (Table 5) and CDVA (Table 6). MRSE and UDVA between the two groups were almost similar on the pre-operative and routine follow-ups. No

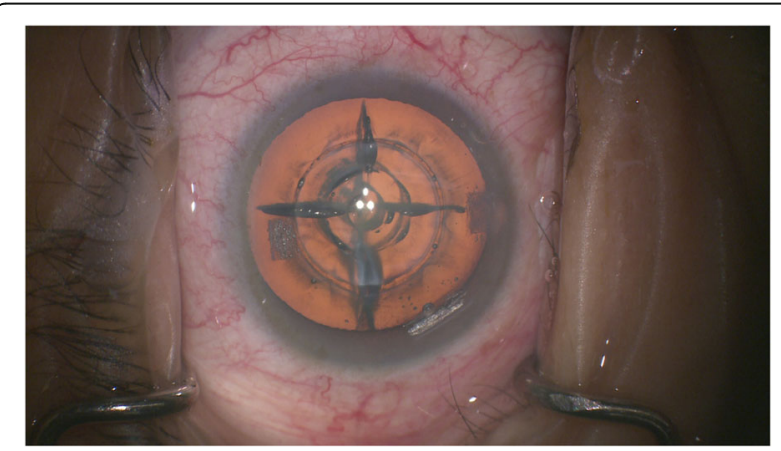

Fig. 5 Post-femtosecond laser treatment showing anterior capsulotomy, lens fragmentation pattern and corneal incisions significant difference between the FLACS and CP groups was noted in the percentage of patients who achieved a CDVA of 20/25 or better (Fig. 7). The multifocal IOLs and accommodating IOLs were also analyzed based on UNVA and DCNVA (Table 7). Overall there was no statistically significant trend seen even with the IOL subgroup analysis.

Intraoperative parameters that were unique to FLACS included capsulotomy quality and incidence of suction break (Table 8 ). In one patient with grade 4 white cataract, an anterior capsular tear occurred while performing the femtosecond laser treatment. The tear was visualized and removal of nucleus and cortical material proceeded with care. The other two anterior capsular tears occurred after manually completing an incomplete laserassisted capsulotomy and a residual bridge. However, all capsular tears did not extend posteriorly and the IOL was placed in the bag for each case with no other complications. The rest of the capsulotomies that were not freely floating were successfully completed manually (Fig. 9). Suction break occurred in 2 instances due to a narrow palpebral fissure and patients squeezing the suction slip (Fig. 10).

The mean values of cumulative dissipated energy (CDE) during phacoemulsification for the FLACS group were lower in all cataract grades compared to the $\mathrm{CP}$

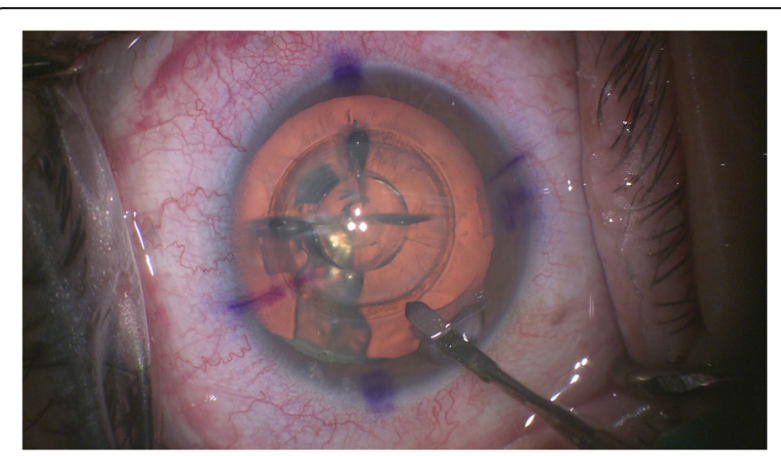

Fig. 6 Corneal incision dissection using a blunt corneal femtodissector instrument 
Table 1 Baseline Demographics

\begin{tabular}{|c|c|c|c|}
\hline & \multicolumn{2}{|c|}{ No. of patients (\%) or Mean \pm SD } & \multirow{2}{*}{$\begin{array}{l}P \\
\text { Value }\end{array}$} \\
\hline & FLACS $(n=296)$ & $\mathrm{CP}(n=439)$ & \\
\hline Age (years) & $67.48 \pm 10.33$ & $65.21 \pm 10.87$ & \\
\hline \multicolumn{4}{|l|}{ Gender } \\
\hline Female & $182(61.50 \%)$ & $175(61.40 \%)$ & 0.99 \\
\hline Male & $114(38.50 \%)$ & $110(38.60 \%)$ & \\
\hline \multicolumn{4}{|l|}{ Visual Acuity (logMAR) } \\
\hline UDVA & $\begin{array}{l}0.78 \pm 0.58 \\
(20 / 125)\end{array}$ & $\begin{array}{l}0.74 \pm 0.54 \\
(20 / 100)\end{array}$ & 0.32 \\
\hline UNVA & $0.50 \pm 0.26(J 8)$ & $0.52 \pm 0.25(J 8)$ & 0.28 \\
\hline CDVA & $0.25 \pm 0.35(20 / 32)$ & $0.21 \pm 0.31(20 / 32)$ & 0.06 \\
\hline DCNVA & $0.46 \pm 0.21(\mathrm{~J} 8)$ & $0.37 \pm 0.22(\mathrm{~J} 6)$ & $0.00^{*}$ \\
\hline \multicolumn{4}{|l|}{ Refraction (D) } \\
\hline Sphere & $-0.77 \pm 3.70$ & $-0.28 \pm 3.82$ & 0.10 \\
\hline Cylinder & $-1.23 \pm 0.82$ & $-1.22 \pm 2.57$ & 0.95 \\
\hline Add & $2.55 \pm 0.46$ & $2.32 \pm 0.68$ & $0.00^{*}$ \\
\hline MRSE & $-1.36 \pm 3.70$ & $-0.86 \pm 3.98$ & 0.09 \\
\hline \multicolumn{4}{|l|}{ LOCS III Cataract Grade } \\
\hline NO1 & $25(8.45 \%)$ & $36(8.20 \%)$ & $0.04^{*}$ \\
\hline $\mathrm{NO} 2$ & $136(45.95 \%)$ & $239(54.44 \%)$ & \\
\hline NO3 & $79(26.69 \%)$ & $111(25.28 \%)$ & \\
\hline $\mathrm{NO} 4$ & $56(18.92 \%)$ & $53(12.07 \%)$ & \\
\hline Average Keratometry (D) & $43.97 \pm 1.72$ & $44.20 \pm 1.69$ & 0.14 \\
\hline \multicolumn{4}{|l|}{ Type of Intraocular Lens } \\
\hline Monofocal & $62(20.95 \%)$ & $77(17.54 \%)$ & \\
\hline Monofocal Toric & $59(19.93 \%)$ & $66(15.03 \%)$ & \\
\hline Multifocal & $81(27.36 \%)$ & 107 (24.37\%) & \\
\hline Multifocal Toric & $53(17.90 \%)$ & 70 (15.95\%) & \\
\hline Accommodating & $41(13.85 \%)$ & 119 (27.11\%) & \\
\hline
\end{tabular}

$C D V A=$ corrected distance visual acuity; $C P=$ conventional phacoemulsification; $D=$ diopter; $D C N V A=$ distance-corrected near visual acuity, $F L A C S=$ femtosecond laser-assisted cataract surgery; LOCS III = Lens Opacities Classification System III; logMAR = logarithm of the minimum angle of resolution; $M R S E$ = manifest refraction spherical equivalent; $N O=$ nuclear opalescence; $S D=$ standard deviation; UDVA = uncorrected distance visual acuity; UNVA = uncorrected near visual acuity

"P $\leq 0.05$

Table 2 Post-operative Manifest Refraction Spherical Equivalent at 1 Year

\begin{tabular}{llll}
\hline & \multicolumn{2}{l}{$\%$} & P Value \\
\cline { 2 - 3 } & FLACS $(n=120)$ & CP $(n=265)$ & \\
\hline$\leq 0.50 \mathrm{D}$ & $65.83 \%(79)$ & $72.45 \%(192)$ & 0.09 \\
$0.51 \mathrm{D}$ to $1.00 \mathrm{D}$ & $24.17 \%(29)$ & $22.26 \%(59)$ & \\
$1.01 \mathrm{D}$ to $1.50 \mathrm{D}$ & $9.17 \%(11)$ & $3.40 \%(9)$ & \\
1.51 D to 2.00 D & $0.83 \%(1)$ & $1.89 \%(5)$ & \\
\hline
\end{tabular}

$C P=$ conventional phacoemulsification; $D=$ diopter; $F L A C S=$ femtosecond laser-assisted cataract surgery

${ }^{*} P \leq 0.05$ group. The CDE was significantly lower with grade 4 cataracts in the FLACS group (Table 9).

Post-operative mean grading for corneal edema, aqueous cells, flare, and endothelial cell loss on specular microscopy were compared in both groups. Post-operative central corneal edema at 1 day, aqueous cells and flare at 1 week and endothelial cell loss at 1 month for FLACS were found to be significantly lower statistically compared to the CP group (Table 10).

\section{Discussion}

The last significant technological revolution in cataract surgery was the introduction of phacoemulsification in the early 1990s. Back then, there was resistance to change because surgeons were already achieving consistently good outcomes from extracapsular cataract surgery with minimal investment in equipment. It took more than a decade of developing new instruments, foldable IOLs and a critical mass of instructors to establish phacoemulsification as the primary procedure of choice for surgeons. We are again at an important point of evolution and change. The femtosecond laser can perform critical steps in cataract surgery that can make the entire procedure more consistent in quality and usher in a new generation of innovations. However, it still needs to be proven whether femtosecond laser-assisted cataract surgery (FLACS) is as safe and can produce better outcomes than the current gold-standard, which is conventional phacoemulsification (CP). In this retrospective review, the authors present their clinical outcomes in order to help answer this important question.

FLACS was first introduced in our practice as an alternative to $\mathrm{CP}$ in 2013. The conversion rate that initial year was at 58\%, with gradual increases in 2014 and 2015 to $60 \%$ and 66\%, respectively. Of those patients who underwent CP over FLACS, 98\% cited cost as the main reason they did not choose FLACS. Of the remaining $2 \%$ of patients, we disqualified them from undergoing FLACS because they had small interpalpebral apertures that may cause problems with docking, poorly dilating pupil that did not reach the size of the intended capsulotomy, and shallow anterior chamber at risk for IOP rise.

In our study, we decided to do a subgroup analysis of refractive and visual outcomes based on the type of IOL to remove any bias related to IOL power targeting between lenses and get a clearer picture if some types of lenses benefit more from the precision of FLACS. We found no significant difference in outcomes up to one year follow up between FLACS and CP, so we benchmarked our results with studies in the literature to confirm our findings.

Filkorn et al. divided their population based on axial length and found that the FLACS group had a 
Table 3 Mean Refractive Spherical Equivalent (logMAR) and Mean Absolute Error (MAE)

\begin{tabular}{|c|c|c|c|c|c|c|c|}
\hline \multirow{2}{*}{$\begin{array}{l}\mathrm{IOL} \\
\text { Grouping }\end{array}$} & \multicolumn{3}{|c|}{ FLACS } & \multicolumn{3}{|l|}{$C P$} & \multirow[t]{2}{*}{$P$ Value } \\
\hline & $\mathrm{n}$ & MRSE \pm SD & $\overline{M A E}$ & $\mathrm{n}$ & $\mathrm{MRSE} \pm \mathrm{SD}$ & MAE & \\
\hline \multicolumn{8}{|c|}{ Overall MRSE } \\
\hline 1 Day & 286 & $-0.17 \pm 0.71$ & 0.17 & 371 & $-0.13 \pm 0.61$ & 0.13 & 0.4383 \\
\hline 1 Week & 283 & $-0.24 \pm 0.53$ & 0.24 & 417 & $-0.21 \pm 0.50$ & 0.21 & 0.4473 \\
\hline 1 Month & 239 & $-0.21 \pm 0.53$ & 0.21 & 367 & $-0.22 \pm 0.52$ & 0.22 & 0.8185 \\
\hline 3 Months & 191 & $-0.22 \pm 0.57$ & 0.22 & 315 & $-0.23 \pm 0.52$ & 0.23 & 0.8399 \\
\hline 6 Months & 164 & $-0.20 \pm 0.66$ & 0.20 & 268 & $-0.24 \pm 0.57$ & 0.24 & 0.5057 \\
\hline 1 Year & 120 & $-0.16 \pm 0.58$ & 0.16 & 265 & $-0.20 \pm 0.52$ & 0.20 & 0.5007 \\
\hline
\end{tabular}

$\begin{array}{lll}1 \text { Day } & 53 & -0.21 \pm 0.63 \\ 1 \text { Week } & 57 & -0.27 \pm 0.46 \\ 1 \text { Month } & 45 & -0.23 \pm 0.34 \\ 3 \text { Months } & 28 & -0.25 \pm 0.35 \\ 6 \text { Months } & 24 & -0.12 \pm 0.78 \\ 1 \text { Year } & 25 & -0.06 \pm 0.53\end{array}$

Monofocal MRSE (target plano)

Monofocal Toric MRSE (target plano)

$\begin{array}{ll}1 \text { Day } & 57 \\ 1 \text { Week } & 59 \\ 1 \text { Month } & 50 \\ 3 \text { Months } & 40 \\ 6 \text { Months } & 36 \\ 1 \text { Year } & 27\end{array}$

$-0.07 \pm 0.59$

$\begin{array}{ll}0.07 & 62 \\ 0.11 & 59 \\ 0.12 & 57 \\ 0.20 & 43 \\ 0.16 & 35 \\ 0.09 & 35\end{array}$

Multifocal MRSE (target plano)

$\begin{array}{ll}1 \text { Day } & 77 \\ 1 \text { Week } & 77 \\ 1 \text { Month } & 60 \\ 3 \text { Months } & 3 \\ 6 \text { Months } & 2 \\ 1 \text { Year } & \end{array}$

$-0.18 \pm 0.70$

0.18

$\begin{array}{ll}0.21 & 45 \\ 0.27 & 65 \\ 0.23 & 53 \\ 0.25 & 40 \\ 0.12 & 33 \\ 0.06 & 32\end{array}$

$-0.03 \pm 0.78$

$$
0.03
$$

$-0.17 \pm 0.56$

$$
0.17
$$$$
-0.13 \pm 0.56
$$

$-0.08 \pm 0.43$

$$
0.08
$$$$
-0.05 \pm 0.50
$$

$$
0.05
$$$$
-0.01 \pm 0.56
$$

0.4383

0.4473

0.8185

0.8399

0.5057

0.5007

$-0.11 \pm 0.70$

$-0.06 \pm 0.53$

0.06

$-0.05 \pm 0.64$

0.05

$-0.11 \pm 0.45$

0.11

$-0.08 \pm 0.52$

0.08

$-0.06 \pm 0.45$

$$
0.06
$$

$-0.03 \pm 0.49$

0.5676

0.2874

0.2986

0.0886

0.6815

\begin{tabular}{|c|c|c|c|c|c|c|c|}
\hline 1 Day & 41 & $-0.33 \pm 0.72$ & 0.17 & 116 & $-0.22 \pm 0.53$ & 0.28 & 0.3023 \\
\hline 1 Week & 40 & $-0.49 \pm 0.60$ & 0.01 & 118 & $-0.32 \pm 0.45$ & 0.18 & 0.0607 \\
\hline 1 Month & 35 & $-0.43 \pm 0.56$ & 0.07 & 113 & $-0.35 \pm 0.50$ & 0.15 & 0.4229 \\
\hline 3 Months & 31 & $-0.55 \pm 0.69$ & 0.05 & 110 & $-0.45 \pm 0.49$ & 0.05 & 0.3636 \\
\hline 6 Months & 26 & $-0.61 \pm 0.59$ & 0.11 & 95 & $-0.50 \pm 0.56$ & 0.00 & 0.3820 \\
\hline 1 Year & 20 & $-0.46 \pm 0.58$ & 0.04 & 95 & $-0.46 \pm 0.50$ & 0.04 & $>0.9999$ \\
\hline
\end{tabular}

0.7334

Multifocal Toric MRSE (target plano)

$\begin{array}{ll}1 \text { Day } & 49 \\ 1 \text { Week } & 43 \\ 1 \text { Month } & 36 \\ 3 \text { Months } & 27 \\ 6 \text { Months } & 24 \\ 1 \text { Year } & 25\end{array}$

Accommodating MRSE (target -0.50 )

$C P$ = conventional phacoemulsification; $F L A C S$ = femtosecond laser-assisted cataract surgery; $I O L$ = intraocular lens; logMAR = logarithm of the minimum angle of resolution; $M A E=$ mean absolute error; $M R S E=$ manifest refraction spherical equivalent; $S D=$ standard deviation

${ }^{*} P<0.05$ 
Table 4 Manifest Refractive Cylinder (Diopter)

\begin{tabular}{llll}
\hline & FLACS & CP & $P$ value \\
\hline 1 Month & $-0.75 \pm 0.46$ & $-0.72 \pm 0.44$ & 0.47 \\
3 Months & $-0.70 \pm 0.40$ & $-0.74 \pm 0.45$ & 0.32 \\
6 Months & $-0.75 \pm 0.48$ & $-0.74 \pm 0.43$ & 0.83 \\
1 Year & $-0.75 \pm 0.50$ & $-0.72 \pm 0.44$ & 0.64 \\
\hline
\end{tabular}

$F L A C S=$ femtosecond laser-assisted cataract surgery; $C P=$ conventional phacoemulsification

significantly lower mean absolute error in spherical equivalent refraction, with the greatest difference in short and long eyes [35]. Ewe et al. reported that in their $\mathrm{CP}$ group, a higher percentage of eyes were within 0.50 $\mathrm{D}$ of error from target refraction and the difference in their study was significant [36]. Conrad-Hengerer et al. investigated manifest refraction and CDVA deviation from target refraction, and refractive stability up to six months post-operatively [37]. FLACS had better refractive results up to 1 week hence stabilized earlier but did not differ significantly compared to CP afterwards [37]. They determined that FLACS is safe and precise, however, only enhanced visual outcomes minimally with a significant difference in refractive deviation but had no clinical relevance [37]. In a study by Miháltz et al., the FLACS and CP groups were compared based on sphere, cylinder, UDVA and CDVA, with the two groups only differing in the method of capsulorhexis [38]. There was also no statistically significant difference at 6 months after surgery. In our study, FLACS had no statistically significant difference compared to $\mathrm{CP}$ for refractive and visual outcomes up to one year follow-up, except for a few time points, which proved temporary. In terms of residual refractive astigmatism (MRSE - Table 3 and Mean Refractive Cylinder - Table 4), no significant difference was noted between FLACS and CP in our single surgeon study, suggesting that the effect is similar whether the corneal incision was made with the laser or manually.

No trend emerged from the analysis of MRSE, UDVA, and CDVA for the different types of IOLs. Overall, manually performed cataract removal for standard cases in the hands of an experienced surgeon provided similar levels of visual acuity results. FLACS demonstrated a comparable visual outcome with $\mathrm{CP}$ but did not establish a clinical visual advantage over it [14, 35-38]. Clinical evidence at this time, including our study, supports this finding and we therefore concur with this observation.

The concept of FLACS and the higher cost associated with it leads the surgeon to expect completely free floating, perfectly symmetrical and consistently sized capsulotomies in each and every case the laser is applied. This is achievable in most cases, but unique types of non-
Table 5 Uncorrected Distance Visual Acuity for All Intraocular Lenses (logMAR)

\begin{tabular}{|c|c|c|c|c|c|}
\hline \multirow{2}{*}{$\begin{array}{l}\mathrm{IOL} \\
\text { Grouping }\end{array}$} & \multicolumn{2}{|c|}{ FLACS } & \multicolumn{2}{|l|}{ CP } & \multirow[t]{2}{*}{$P$ Value } \\
\hline & $\mathrm{n}$ & Mean \pm SD & $\mathrm{n}$ & Mean \pm SD & \\
\hline \multicolumn{6}{|l|}{ Overall UDVA } \\
\hline 1 Day & 293 & $0.17 \pm 0.17(20 / 25)$ & 427 & $0.15 \pm 0.19(20 / 25)$ & 0.15 \\
\hline 1 Week & 282 & $0.13 \pm 0.14(20 / 25)$ & 420 & $0.11 \pm 0.14(20 / 25)$ & 0.06 \\
\hline 1 Month & 244 & $0.13 \pm 0.15(20 / 25)$ & 369 & $0.11 \pm 0.15(20 / 25)$ & 0.11 \\
\hline 3 Months & 191 & $0.12 \pm 0.13(20 / 25)$ & 315 & $0.12 \pm 0.14(20 / 25)$ & 1.00 \\
\hline 6 Months & 162 & $0.12 \pm 0.14(20 / 25)$ & 268 & $0.10 \pm 0.13(20 / 25)$ & 0.13 \\
\hline 1 Year & 120 & $0.12 \pm 0.13(20 / 25)$ & 265 & $0.11 \pm 0.13(20 / 25)$ & 0.48 \\
\hline \multicolumn{6}{|c|}{ Monofocal UDVA } \\
\hline 1 Day & 59 & $0.15 \pm 0.15(20 / 25)$ & 67 & $0.16 \pm 0.22(20 / 25)$ & 0.08 \\
\hline 1 Week & 58 & $0.13 \pm 0.14(20 / 25)$ & 65 & $0.13 \pm 0.19(20 / 25)$ & 1.00 \\
\hline 1 Month & 47 & $0.15 \pm 0.16(20 / 25)$ & 54 & $0.13 \pm 0.17(20 / 25)$ & 0.55 \\
\hline 3 Months & 28 & $0.13 \pm 0.15(20 / 25)$ & 39 & $0.14 \pm 0.15(20 / 25)$ & 0.08 \\
\hline 6 Months & 23 & $0.13 \pm 0.13(20 / 25)$ & 34 & $0.14 \pm 0.16(20 / 25)$ & 0.80 \\
\hline 1 Year & 25 & $0.12 \pm 0.13(20 / 25)$ & 32 & $0.12 \pm 0.13(20 / 25)$ & 1.00 \\
\hline \multicolumn{6}{|c|}{ Monofocal Toric UDVA } \\
\hline 1 Day & 57 & $0.15 \pm 0.14(20 / 25)$ & 63 & $0.13 \pm 0.12(20 / 25)$ & 0.40 \\
\hline 1 Week & 59 & $0.21 \pm 0.16(20 / 32)$ & 66 & $0.15 \pm 0.20(20 / 25)$ & 0.07 \\
\hline 1 Month & 51 & $0.18 \pm 0.16(20 / 25)$ & 58 & $0.12 \pm 0.18(20 / 25)$ & 0.07 \\
\hline 3 Months & 39 & $0.16 \pm 0.13(20 / 25)$ & 43 & $0.14 \pm 0.15(20 / 25)$ & 0.52 \\
\hline 6 Months & 37 & $0.16 \pm 0.14(20 / 25)$ & 34 & $0.10 \pm 0.12(20 / 25)$ & 0.06 \\
\hline 1 Year & 27 & $0.16 \pm 0.15(20 / 25)$ & 34 & $0.15 \pm 0.13(20 / 25)$ & 0.78 \\
\hline \multicolumn{6}{|c|}{ Multifocal UDVA } \\
\hline 1 Day & 78 & $0.18 \pm 0.19(20 / 25)$ & 101 & $0.15 \pm 0.20(20 / 25)$ & 0.31 \\
\hline 1 Week & 75 & $0.13 \pm 0.15(20 / 25)$ & 99 & $0.11 \pm 0.13(20 / 25)$ & 0.35 \\
\hline 1 Month & 62 & $0.11 \pm 0.14(20 / 25)$ & 85 & $0.12 \pm 0.15(20 / 25)$ & 0.68 \\
\hline 3 Months & 43 & $0.10 \pm 0.12(20 / 25)$ & 70 & $0.13 \pm 0.17(20 / 25)$ & 0.31 \\
\hline 6 Months & 30 & $0.11 \pm 0.15(20 / 25)$ & 51 & $0.12 \pm 0.14(20 / 25)$ & 0.76 \\
\hline 1 Year & 21 & $0.10 \pm 0.12(20 / 25)$ & 50 & $0.11 \pm 0.12(20 / 25)$ & 0.75 \\
\hline \multicolumn{6}{|c|}{ Multifocal Toric UDVA } \\
\hline 1 Day & 49 & $0.13 \pm 0.12(20 / 25)$ & 67 & $0.15 \pm 0.17(20 / 25)$ & 0.48 \\
\hline 1 Week & 43 & $0.20 \pm 0.24(20 / 32)$ & 69 & $0.18 \pm 0.18(20 / 25)$ & 0.62 \\
\hline 1 Month & 36 & $0.13 \pm 0.14(20 / 25)$ & 53 & $0.15 \pm 0.14(20 / 25)$ & 0.51 \\
\hline 3 Months & 27 & $0.10 \pm 0.11(20 / 25)$ & 48 & $0.17 \pm 0.14(20 / 25)$ & $0.03^{*}$ \\
\hline 6 Months & 24 & $0.18 \pm 0.15(20 / 25)$ & 48 & $0.13 \pm 0.13(20 / 25)$ & 0.15 \\
\hline 1 Year & 25 & $0.10 \pm 0.14(20 / 25)$ & 52 & $0.16 \pm 0.14(20 / 25)$ & 0.08 \\
\hline \multicolumn{6}{|c|}{ Accommodating UDVA } \\
\hline 1 Day & 41 & $0.14 \pm 0.14(20 / 25)$ & 116 & $0.14 \pm 0.16(20 / 25)$ & 1.00 \\
\hline 1 Week & 40 & $0.15 \pm 0.15(20 / 25)$ & 118 & $0.08 \pm 0.12(20 / 20)$ & $0.00^{*}$ \\
\hline 1 Month & 35 & $0.12 \pm 0.14(20 / 25)$ & 113 & $0.07 \pm 0.11(20 / 20)$ & $0.03^{*}$ \\
\hline 3 Months & 31 & $0.14 \pm 0.15(20 / 25)$ & 113 & $0.00 \pm 0.01(20 / 20)$ & $0.00^{*}$ \\
\hline 6 Months & 25 & $0.12 \pm 0.12(20 / 25)$ & 95 & $0.08 \pm 0.12(20 / 20)$ & 0.14 \\
\hline 1 Year & 20 & $0.12 \pm 0.14(20 / 25)$ & 94 & $0.07 \pm 0.10(20 / 20)$ & 0.06 \\
\hline
\end{tabular}

$C P=$ conventional phacoemulsification; $F L A C S=$ femtosecond laser-assisted cataract surgery; $I O L=$ intraocular lens; $\log M A R=$ logarithm of the minimum angle of resolution; $S D=$ standard deviation; UDVA = uncorrected distance visual acuity

${ }^{*} P \leq 0.05$ 
Table 6 Corrected Distance Visual Acuity for All Intraocular Lenses (logMAR)

\begin{tabular}{lllll}
\hline $\mathrm{IOL}$ & $\mathrm{FLACS}$ & $\mathrm{CP}$ & PValue \\
& $\mathrm{n}$ Mean $\pm \mathrm{SD}$ & $\mathrm{n}$ Mean $\pm \mathrm{SD}$ & \\
\hline
\end{tabular}

Overall CDVA

$\begin{array}{llllll}1 \text { Day } & 285 & 0.09 \pm 0.14(20 / 20) & 363 & 0.07 \pm 0.13(20 / 20) & 0.06 \\ 1 \text { Week } & 278 & 0.05 \pm 0.09(20 / 20) & 411 & 0.04 \pm 0.08(20 / 20) & 0.13 \\ 1 \text { Month } & 236 & 0.05 \pm 0.09(20 / 20) & 357 & 0.03 \pm 0.07(20 / 20) & 0.00^{*} \\ 3 \text { Months } & 191 & 0.03 \pm 0.08(20 / 20) & 312 & 0.03 \pm 0.07(20 / 20) & 1.00 \\ 6 \text { Months } & 161 & 0.04 \pm 0.08(20 / 20) & 266 & 0.03 \pm 0.07(20 / 20) & 0.18 \\ 1 \text { Year } & 120 & 0.03 \pm 0.07(20 / 20) & 265 & 0.02 \pm 0.06(20 / 20) & 0.15\end{array}$

Monofocal CDVA

$\begin{array}{llllll}1 \text { Day } & 53 & 0.08 \pm 0.12(20 / 20) & 43 & 0.06 \pm 0.11(20 / 20) & 0.40 \\ 1 \text { Week } & 54 & 0.05 \pm 0.09(20 / 20) & 64 & 0.04 \pm 0.09(20 / 20) & 0.55 \\ 1 \text { Month } & 43 & 0.07 \pm 0.11(20 / 20) & 52 & 0.03 \pm 0.09(20 / 20) & 0.05 \\ 3 \text { Months } & 28 & 0.07 \pm 0.12(20 / 20) & 40 & 0.03 \pm 0.06(20 / 20) & 0.07 \\ 6 \text { Months } & 22 & 0.04 \pm 0.08(20 / 20) & 33 & 0.04 \pm 0.08(20 / 20) & 1.00 \\ 1 \text { Year } & 24 & 0.04 \pm 0.08(20 / 20) & 32 & 0.01 \pm 0.04(20 / 20) & 0.07\end{array}$

Monofocal Toric CDVA

$\begin{array}{llllll}1 \text { Day } & 57 & 0.05 \pm 0.10(20 / 20) & 60 & 0.05 \pm 0.09(20 / 20) & 1.00 \\ 1 \text { Week } & 59 & 0.11 \pm 0.16(20 / 25) & 55 & 0.08 \pm 0.13(20 / 20) & 0.28 \\ 1 \text { Month } & 50 & 0.06 \pm 0.12(20 / 20) & 55 & 0.05 \pm 0.09(20 / 20) & 0.63 \\ 3 \text { Months } & 40 & 0.04 \pm 0.09(20 / 20) & 41 & 0.06 \pm 0.10(20 / 20) & 0.00^{*} \\ 6 \text { Months } & 36 & 0.04 \pm 0.07(20 / 20) & 35 & 0.05 \pm 0.08(20 / 20) & 0.58 \\ 1 \text { Year } & 27 & 0.03 \pm 0.07(20 / 20) & 35 & 0.07 \pm 0.09(20 / 20) & 0.06\end{array}$
Multifocal CDVA

$\begin{array}{llllll}1 \text { Day } & 77 & 0.10 \pm 0.14(20 / 25) & 101 & 0.08 \pm 0.15(20 / 20) & 0.37 \\ 1 \text { Week } & 75 & 0.05 \pm 0.10(20 / 20) & 97 & 0.04 \pm 0.08(20 / 20) & 0.47 \\ 1 \text { Month } & 59 & 0.05 \pm 0.09(20 / 20) & 83 & 0.03 \pm 0.06(20 / 20) & 0.11 \\ 3 \text { Months } & 43 & 0.03 \pm 0.06(20 / 20) & 69 & 0.03 \pm 0.07(20 / 20) & 1.00 \\ 6 \text { Months } & 31 & 0.04 \pm 0.09(20 / 20) & 49 & 0.03 \pm 0.07(20 / 20) & 0.58 \\ 1 \text { Year } & 21 & 0.02 \pm 0.07(20 / 20) & 48 & 0.03 \pm 0.07(20 / 20) & 0.59\end{array}$
Multifocal Toric CDVA

$\begin{array}{llllll}1 \text { Day } & 49 & 0.04 \pm 0.11(20 / 20) & 66 & 0.06 \pm 0.11(20 / 20) & 0.34 \\ 1 \text { Week } & 43 & 0.10 \pm 0.16(20 / 25) & 58 & 0.09 \pm 0.14(20 / 20) & 0.74 \\ 1 \text { Month } & 36 & 0.04 \pm 0.07(20 / 20) & 53 & 0.05 \pm 0.09(20 / 20) & 0.58 \\ 3 \text { Months } & 27 & 0.03 \pm 0.08(20 / 20) & 48 & 0.04 \pm 0.08(20 / 20) & 0.60 \\ 6 \text { Months } & 24 & 0.03 \pm 0.09(20 / 20) & 48 & 0.04 \pm 0.09(20 / 20) & 0.66 \\ 1 \text { Year } & 25 & 0.02 \pm 0.14(20 / 20) & 52 & 0.03 \pm 0.07(20 / 20) & 0.68\end{array}$
Accommodating CDVA

$\begin{array}{llllll}1 \text { Day } & 40 & 0.02 \pm 0.04(20 / 20) & 115 & 0.05 \pm 0.12(20 / 20) & 0.12 \\ 1 \text { Week } & 40 & 0.04 \pm 0.08(20 / 20) & 118 & 0.02 \pm 0.05(20 / 20) & 0.07 \\ 1 \text { Month } & 35 & 0.01 \pm 0.03(20 / 20) & 113 & 0.01 \pm 0.03(20 / 20) & 1.00 \\ 3 \text { Months } & 30 & 0.00 \pm 0.02(20 / 20) & 110 & 0.00 \pm 0.02(20 / 20) & 1.00\end{array}$

Table 6 Corrected Distance Visual Acuity for All Intraocular Lenses (logMAR) (Continued)

\begin{tabular}{|c|c|c|c|c|c|}
\hline \multirow{2}{*}{$\begin{array}{l}\text { IOL } \\
\text { Grouping }\end{array}$} & \multicolumn{2}{|c|}{ FLACS } & \multicolumn{2}{|l|}{$\mathrm{CP}$} & \multirow[t]{2}{*}{$P$ Value } \\
\hline & $\mathrm{n}$ & Mean \pm SD & $\mathrm{n}$ & Mean \pm SD & \\
\hline 6 Months & 25 & $0.02 \pm 0.06(20 / 20)$ & 95 & $0.00 \pm 0.02(20 / 20)$ & $0.01^{*}$ \\
\hline 1 Year & 20 & $0.01 \pm 0.05(20 / 20)$ & 95 & $0.00 \pm 0.03(20 / 20)$ & 0.24 \\
\hline
\end{tabular}

completion lead us to categorize these occurrences as complications. Even in stricter terms, it can be interpreted as non-fulfillment of the expectations of tasks the laser had to perform. These so-called complications uniquely encountered in FLACS cases include non-free floating capsulotomies, anterior capsular tears, and suction breaks. Our anterior capsular tear rate was low and we had zero incidence of posterior capsular extension in the FLACS group. Reports from other studies ranged from 0 to $5.3 \%$ for the anterior capsular tear rate and a maximum of $50 \%$ incidence of extension to the posterior capsule when an anterior capsular tear occurred [10, $20-22,25,26,39]$. In our study, an anterior capsular tear occurred during FLACS of a patient with grade 4 white cataract. The egress of milky fluid can pose a challenge during capsulotomy even though the study by ConradHengerer et al. reported that FLACS is safe and technically feasible in intumescent white cataracts, stating that capsule tears occur less frequently in FLACS compared to CP [27]. Complications listed by other studies but not

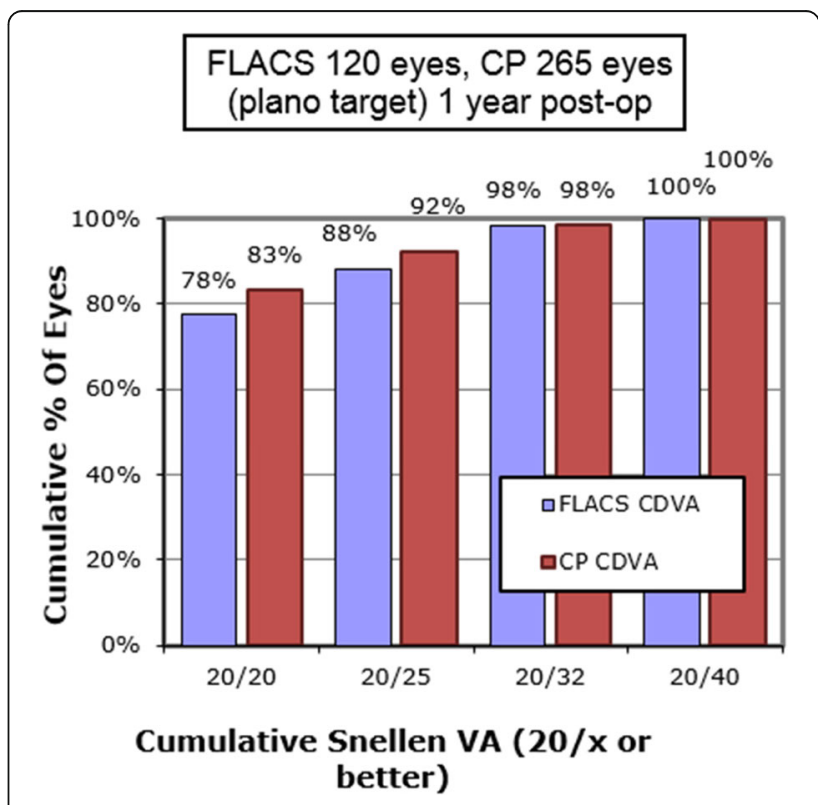

Fig. 7 Post-operative corrected distance visual acuity at 1 year per Snellen Chart 
Table 7 Near Visual Acuity for Multifocals and Accommodating Intraocular Lenses (logMAR)

\begin{tabular}{llllll}
\hline $\mathrm{IOL}$ & $\mathrm{FLACS}$ & & $\mathrm{CP}$ & PValue \\
& $\mathrm{n}$ Mrouping & Mean $\pm \mathrm{SD}$ & & Mean $\pm \mathrm{SD}$ & \\
\hline
\end{tabular}

Multifocal UNVA

$\begin{array}{llllll}1 \text { Day } & 78 & 0.18 \pm 0.20(\mathrm{~J} 3) & 81 & 0.13 \pm 0.16(\mathrm{~J} 2) & 0.08 \\ 1 \text { Week } & 74 & 0.10 \pm 0.15(\mathrm{~J} 2) & 82 & 0.10 \pm 0.12(\mathrm{~J} 2) & 1.00 \\ \text { 1 Month } & 60 & 0.11 \pm 0.15(\mathrm{~J} 2) & 68 & 0.08 \pm 0.08(\mathrm{~J} 1) & 0.15 \\ \text { 3 Months } & 42 & 0.09 \pm 0.14(\mathrm{~J} 1) & 57 & 0.11 \pm 0.12(\mathrm{~J} 2) & 0.45 \\ \text { 6 Months } & 30 & 0.08 \pm 0.15(\mathrm{~J} 1) & 41 & 0.09 \pm 0.10(\mathrm{~J} 1) & 0.74 \\ 1 \text { Year } & 21 & 0.10 \pm 0.11(\mathrm{~J} 2) & 40 & 0.12 \pm 0.12(\mathrm{~J} 2) & 0.53\end{array}$

\section{Multifocal DCNVA}

$\begin{array}{llllll}1 \text { Day } & 77 & 0.16 \pm 0.19(\mathrm{~J} 2) & 79 & 0.14 \pm 0.20(\mathrm{~J} 2) & 0.52 \\ 1 \text { Week } & 74 & 0.07 \pm 0.12(\mathrm{~J} 1) & 74 & 0.10 \pm 0.13(\mathrm{~J} 2) & 0.15 \\ \text { 1 Month } & 57 & 0.08 \pm 0.12(\mathrm{~J} 1) & 59 & 0.06 \pm 0.09(\mathrm{~J} 1) & 0.31 \\ \text { 3 Months } & 42 & 0.05 \pm 0.08(\mathrm{~J} 1) & 53 & 0.10 \pm 0.12(\mathrm{~J} 2) & 0.02^{*} \\ \text { 6 Months } & 30 & 0.06 \pm 0.10(\mathrm{~J} 1) & 36 & 0.07 \pm 0.11(\mathrm{~J} 1) & 0.70 \\ 1 \text { Year } & 21 & 0.09 \pm 0.11(\mathrm{~J} 1) & 38 & 0.09 \pm 0.14(\mathrm{~J} 1) & 1.00\end{array}$

Accommodating UNVA

$\begin{array}{llllll}1 \text { Day } & 39 & 0.23 \pm 0.14(\mathrm{~J} 4) & 115 & 0.17 \pm 0.12(\mathrm{~J} 2) & 0.01 \\ 1 \text { Week } & 39 & 0.29 \pm 0.16(\mathrm{~J} 4) & 112 & 0.23 \pm 0.14(\mathrm{~J} 4) & 0.03 \\ 1 \text { Month } & 34 & 0.22 \pm 0.15(\mathrm{~J} 4) & 111 & 0.15 \pm 0.11(\mathrm{~J} 2) & 0.00^{*} \\ 3 \text { Months } & 30 & 0.18 \pm 0.14(\mathrm{~J} 3) & 110 & 0.14 \pm 0.11(\mathrm{~J} 2) & 0.10 \\ 6 \text { Months } & 25 & 0.15 \pm 0.11(\mathrm{~J} 2) & 94 & 0.14 \pm 0.10(\mathrm{~J} 2) & 0.66 \\ 1 \text { Year } & 17 & 0.19 \pm 0.16(\mathrm{~J} 3) & 93 & 0.13 \pm 0.13(\mathrm{~J} 2) & 0.09\end{array}$

Accommodating DCNVA

$\begin{array}{llllll}1 \text { Day } & 30 & 0.27 \pm 0.15(\mathrm{~J} 4) & 115 & 0.24 \pm 0.14(\mathrm{~J} 4) & 0.30 \\ 1 \text { Week } & 22 & 0.33 \pm 0.19(\mathrm{~J} 5) & 112 & 0.22 \pm 0.14(\mathrm{~J} 4) & 0.00^{*} \\ 1 \text { Month } & 26 & 0.25 \pm 0.12(\mathrm{~J} 4) & 111 & 0.19 \pm 0.12(\mathrm{~J} 3) & 0.00^{*} \\ 3 \text { Months } & 22 & 0.21 \pm 0.11(\mathrm{~J} 4) & 105 & 0.17 \pm 0.12(\mathrm{~J} 2) & 0.15 \\ 6 \text { Months } & 19 & 0.17 \pm 0.11(\mathrm{~J} 2) & 91 & 0.19 \pm 0.12(\mathrm{~J} 3) & 0.50 \\ 1 \text { Year } & 13 & 0.25 \pm 0.12(\mathrm{~J} 4) & 91 & 0.19 \pm 0.12(\mathrm{~J} 3) & 0.09\end{array}$

$C P=$ conventional phacoemulsification; $D C N V A=$ distance-corrected near visual acuity; $F L A C S=$ femtosecond laser-assisted cataract surgery; $I O L=$ intraocular lens; $\log M A R=\log$ arithm of the minimum angle of resolution; $S D=$ standard deviation; UNVA = uncorrected near visual acuity

${ }^{*} P \leq 0.05$

encountered by the surgeon in the charts reviewed except for subconjunctival hemorrhage include corneal haze affecting the surgical view, laser-induced miosis, anterior capsulotomy tag, posterior capsular rupture, dropped nucleus, capsular block syndrome, endothelial damage due to laser cuts within the endothelial layer, and docking attempts [10, 20-22, 25, 26, 39]. The FLACS complications noted in our study did not decrease in incidence over the 3 years hence were not
Table 8 Femtosecond Laser Treatment Complications

\begin{tabular}{ll}
\hline & FLACS $(n=296)$ No. of patients (\%) \\
\hline Capsulotomy & \\
Adhesion & $26(8.78 \%)$ \\
Bridge & $3(1.01 \%)$ \\
Incomplete & $2(0.68 \%)$ \\
Anterior Capsular Tear & $3(1.01 \%)$ \\
Posterior Capsular Tear & $0(0 \%)$ \\
Suction Break & $2(0.68 \%)$ \\
\hline
\end{tabular}

attributable to inadequate surgeon experience and were not correlated to the grade of the cataract.

A suction force is applied on the eye to stabilize its position as the laser is firing. Our definition of suction break is non-completion of the femtosecond laser procedures of capsulotomy, lens fragmentation and corneal incisions because the attachment of the eye to the patient interface of the laser was released prematurely. We had 0. $68 \%$ incidence that fell within the range of other studies varying from 0 to $2.5 \%[20-22,39]$. The suction breaks were attributed to small palpebral fissures and patients squeezing the clip until the suction force was broken. Other main risk factors include inadvertent eye or head movement of the patient, improper docking, and loose conjunctiva around the limbus [21]. The most important factors to prevent suction breaks are precise patient interface placement and sufficient preoperative topical anesthesia [21]. A suction break is not a major concern because whatever steps were not performed by the femtosecond laser can be completed manually by the surgeon.

Perhaps the most significant benefit a patient receives when having a FLACS procedure is less ultrasonic energy delivered into the anterior chamber because the cataractous lens has been pre-cut. Ultrasonic energy during phacoemulsification can be quantified either by cumulative dissipated energy (CDE) or effective phacoemulsification time (EPT). CDE is effective phacoemulsification time (EPT) in minutes divided by 100 while EPT

Table 9 Cumulative Dissipated Energy During Phacoemulsification

\begin{tabular}{|c|c|c|c|c|c|}
\hline \multirow{2}{*}{$\begin{array}{l}\text { LOCS III } \\
\text { Grade }\end{array}$} & \multicolumn{2}{|c|}{ FLACS } & \multicolumn{2}{|l|}{$\mathrm{CP}$} & \multirow[t]{2}{*}{$P$ Value } \\
\hline & $n$ & $\begin{array}{l}\text { CDE (percent- } \\
\text { seconds) } \\
\text { Mean } \pm \text { SD }\end{array}$ & $n$ & $\begin{array}{l}\text { CDE (percent- } \\
\text { seconds) } \\
\text { Mean } \pm \text { SD }\end{array}$ & \\
\hline NO1 & 25 & $6.97 \pm 5.74$ & 36 & $7.59 \pm 6.42$ & 0.70 \\
\hline $\mathrm{NO} 2$ & 136 & $14.23 \pm 8.86$ & 239 & $15.34 \pm 10.33$ & 0.29 \\
\hline NO3 & 79 & $26.86 \pm 10.73$ & 111 & $27.02 \pm 9.78$ & 0.92 \\
\hline $\mathrm{NO} 4$ & 56 & $29.02 \pm 16.07$ & 53 & $35.69 \pm 18.30$ & $0.05^{*}$ \\
\hline
\end{tabular}

$C D E$ = cumulative dissipated energy; $C P=$ conventional phacoemulsification; FLACS = femtosecond laser-assisted cataract surgery; LOCS III = Lens Opacities Classification System III; NO = nuclear opalescence; $S D=$ standard deviation ${ }^{*} P \leq 0.05$ 
Table 10 Post-operative Corneal Edema, Cells and Flare, and Endothelial Cell Loss

\begin{tabular}{|c|c|c|c|c|c|}
\hline & \multicolumn{2}{|c|}{ FLACS } & \multicolumn{2}{|l|}{$\mathrm{CP}$} & \multirow[t]{2}{*}{$P$ Value } \\
\hline & $n$ & Mean \pm SD & $n$ & Mean \pm SD & \\
\hline \multicolumn{6}{|c|}{$\begin{array}{l}\text { Corneal Edema }{ }^{a} \\
\text { (Central) }\end{array}$} \\
\hline 1 Day & 263 & $0.65 \pm 0.67$ & 196 & $0.78 \pm 0.73$ & $0.05^{*}$ \\
\hline 1 Week & 170 & $0.05 \pm 0.21$ & 88 & $0.07 \pm 0.24$ & 0.49 \\
\hline \multicolumn{6}{|c|}{$\begin{array}{l}\text { Corneal Edema }{ }^{a} \\
\text { (Peripheral) }\end{array}$} \\
\hline 1 Day & 142 & $1.03 \pm 0.77$ & 79 & $1.02 \pm 0.62$ & 0.92 \\
\hline 1 Week & 85 & $0.14 \pm 0.36$ & 44 & $0.13 \pm 0.34$ & 0.88 \\
\hline \multicolumn{6}{|c|}{$\begin{array}{l}\text { Aqueous } \\
\text { Cells and Flare }\end{array}$} \\
\hline 1 Day & 140 & $0.96 \pm 0.59$ & 72 & $1.04 \pm 0.54$ & 0.34 \\
\hline 1 Week & 80 & $0.03 \pm 0.16$ & 42 & $0.16 \pm 0.40$ & $0.01^{*}$ \\
\hline \multicolumn{6}{|c|}{ ECD (cells $/ \mathrm{mm}^{2}$ ) } \\
\hline Baseline & 283 & $2602.24 \pm 497.30$ & 353 & $2631.28 \pm 387.42$ & 0.41 \\
\hline 1 Month & 189 & $2443.67 \pm 658.78$ & 69 & $2377.26 \pm 459.82$ & 0.66 \\
\hline EC Loss & 189 & $175.23 \pm 649.54$ & 69 & $351.52 \pm 454.21$ & $0.04^{*}$ \\
\hline
\end{tabular}

$E C=$ endothelial cell $; E C D=$ endothelial cell density; $C P=$ conventional phacoemulsification; $F L A C S=$ femtosecond laser-assisted cataract surgery; $S D=$ standard deviation

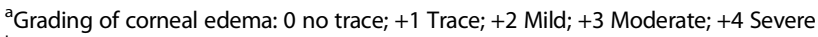
${ }^{\mathrm{b}}$ Standardization of Uveitis Nomenclature (SUN) Working Group Classification for anterior chamber inflammation

"P-value $<0.05$

is phacoemulsification time in seconds multiplied by the average phacoemulsification power in percentage [40]. In the literature, all authors agree that FLACS significantly reduced EPT compared to CP [9, 14, 15, 17, 18]. In our study, the CDE values for FLACS were all lower compared to CP per cataract grade but the statistically significant difference was noted for grade 4 cataracts. Further reduction of EPT was proposed by Abell et al. through optimization of lens fragmentation patterns and surgical technique, with zero EPT as a possibility [14]. FLACS can be most beneficial for mature cataracts, those with zonular compromise and with compromised corneas since decreased EPT will be deemed crucial for these [36]. No study has been published on the advantage of FLACS over CP for such cases [36].

Less phacoemulsification ultrasonic energy in FLACS ideally translates to less corneal edema, less anterior chamber inflammation and a reduced loss of endothelial cell count. Central corneal edema for FLACS in our study was statistically lower post-operatively at 1 day but the difference was not significant by 1 week. Peripheral corneal edema in FLACS was higher than CP due to higher laser energy delivered to create the corneal main incision but the difference with $\mathrm{CP}$ was not statistically significant. Abell et al. had similar central corneal edema findings, with statistically significant reduction in corneal edema for FLACS one day post-operatively but no difference at three weeks [18].
Anterior chamber cells and flare were significantly lower with FLACS at one week after surgery. This finding was consistent with Abell et al. and was attributed to decreased EPT in FLACS [17]. Endothelial cell loss was statistically significantly lower for FLACS compared to $\mathrm{CP}$ one month after surgery. Conrad-Hengerer et al. studied the mean endothelial cell loss of FLACS compared to $\mathrm{CP}$ up to 3 months follow-up and found that FLACS did not add to the endothelial damage and may be favorable in cases of low preoperative endothelial cell values [19].

The present study has several limitations. First is the absence of randomization due to its retrospective nature. Second, the study highlights the real-world scenario wherein the ability or willingness of the patient to pay out of pocket to have femtosecond laser assisted cataract surgery was the most common deciding factor, not a medical indication, for selection of femtosecond laser versus manual phacoemulsification. Third is the preference of the surgeon to use toric IOL implantation rather than using the femtosecond laser limbal relaxing incision (LRI) option. The unused benefit of femtosecond laser LRI could have affected refractive outcomes but in clinical practice, the surgeon has the prerogative to use the features of a technology in that they are most comfortable with.

Overall, FLACS has two clear benefits. First is delivery of lower phacoemulsification energy resulting in reduced endothelial cell loss and less anterior chamber inflammation. Second is providing a consistent capsulotomy that can help an inexperienced surgeon with this crucial step but can also help any surgeon when the anterior capsule opening needs to be consistently sized for specific intraocular lenses. With these benefits, FLACS may be particularly beneficial in complex cases with greater risk for corneal endothelial decompensation. These include patients diagnosed with hypermature cataracts, Fuchs dystrophy or those with highly brunescent nuclei. Cases with loose zonular fibers may also benefit from the automated capsulotomy of femtosecond laser as it spares the zonules from the additional stress of manually tugging on the anterior capsule.

At this time, these advantages have not translated to statistically better refractive and visual outcomes compared to conventional phacoemulsification. Reports continue to be published in the literature as experience grows. Admittedly, cost is an issue and perhaps the main hindrance to widespread adaptation of this technology. However, we see no disadvantage of FLACS over $\mathrm{CP}$ whether from the literature or based on our experience. We recommend that the option of FLACS be explained objectively to each patient and allow them to decide whether the benefits of FLACS outweigh their cost considerations. 


\section{Conclusion}

Femtosecond laser-assisted cataract surgery and conventional phacoemulsification had similar refractive and visual outcomes. Use of femtosecond laser in cataract surgery was efficient and safe. Femtosecond laser-assisted cataract surgery reduced the phacoemulsification energy, decreased the amount of corneal endothelial cell loss and resulted in lesser anterior chamber inflammation compared with conventional phacoemulsification.

\begin{abstract}
Abbreviations
CDVA: Corrected distance visual acuity; CP: Conventional phacoemulsification; D: Diopter; DCNVA: Distance-corrected near visual acuity; EC: Endothelial cell; ECD: Endothelial cell density; FLACS: Femtosecond laser-assisted cataract surgery; IOL: Intraocular lens; LOCS III: Lens Opacities Classification System III; logMAR: logarithm of the minimum angle of resolution; MRSE: Manifest refraction spherical equivalent; NO: Nuclear opalescence; SD: Standard deviation; SUN: Standardization of Uveitis Nomenclature; UDVA: Uncorrected distance visual acuity; UNVA: Uncorrected near visual acuity
\end{abstract}

\section{Acknowledgements}

Statisticians: Ma. Khristine Calvario, Reginald Arimado.

\section{Availability of data and materials}

Available from the corresponding author on reasonable request.

\section{Authors' contributions}

Design and conduct of the study (RTA); collection (MSQ, EMC, MRR), management (RTA), analysis (RTA, MSQ, EMC, MRR, GAM), interpretation of the data (MSQ, RTA, EMC); manuscript preparation (RTA, MSQ, EMC, MRR, GAM), manuscript review (RTA, MSQ, EMC), manuscript approval (RTA, MSQ, EMC). All authors read and approved the final manuscript.

\section{Ethics approval and consent to participate}

Applicable

\section{Competing interests}

Consultant / advisory positions: RTA: Acufocus, Allergan, Bausch \& Lomb, Santen, Medicem, Physiol, Staar. All other authors declare no competing interests.

Received: 19 December 2017 Accepted: 7 April 2018

Published online: 23 April 2018

\section{References}

1. World Health Organization. Vision 2020. The Right to Sight. Global Initiative for the Elimination of Avoidable Blindness; Action Plan 2006-2011. Geneva, Switzerland, 2007. http://www.who.int/blindness/Vision2020_report.pdf. Accessed 6 Apr 2016.

2. Palanker DV, Blumenkranz MS, Andersen D, Wiltberger M, Marcellino G, Gooding $P$, et al. Femtosecond laser-assisted cataract surgery with integrated optical coherence tomography. Sci Transl Med. 2010;2(58):58ra85.

3. Chen $\mathrm{H}$, Hyatt T, Afshari N. Visual and refractive outcomes of laser cataract surgery. Curr Opin Ophthalmol. 2014;25(1):49-53.

4. He L, Sheehy K, Culbertson W. Femtosecond laser-assisted cataract surgery. Curr Opin Ophthalmol. 2011;22(1):43-52.

5. Nagy Z, Takacs A, Filkorn T, Sarayba M. Initial clinical evaluation of an intraocular femtosecond laser in cataract surgery. J Refract Surg. 2009;25: 1053-60.

6. Stodola E. Cataract editor's corner of the world: A variety of femtosecond laser options. Oct. 2013. http://www.eyeworld.org/article-a-variety-offemtosecond-laser-options. Accessed 6 Apr 2016.

7. Szigeti A, Kránitz K, Takacs Al, Miháltz K, Knorz MC, Nagy ZZ. Comparison of long-term visual outcome and IOL position with a single-optic accommodating IOL after 5.5- or 6.0-mm femtosecond laser capsulotomy. J Refract Surg. 2012;28(9):609-13.

8. Grewal DS, Basti S. Comparison of morphologic features of clear corneal incisions created with a femtosecond laser or a keratome. J Cataract Refract Surg. 2014;40:521-30.
9. Reddy KP, Kandulla J, Auffarth GU. Effectiveness and safety of femtosecond laser-assisted lens fragmentation and anterior capsulotomy versus the manual technique in cataract surgery. J Cataract Refract Surg. 2013;39:1297-306.

10. Day AC, Gartry DS, Maurino V, Allan BD, Stevens JD. Efficacy of anterior capsulotomy creation in femtosecond laser-assisted cataract surgery. J Cataract Refract Surg. 2014;40:2031-4.

11. Nagy ZZ, Kránitz K, Takacs Al, Miháltz K, Kovács I, Knorz MC. Comparison of intraocular lens decentration parameters after femtosecond and manual capsulotomies. J Refract Surg. 2011;27:564-9.

12. Mastropasqua L, Toto L, Calienno R, Mattei PA, Mastropasqua A, Vecchiarino L, et al. Scanning electron microscopy evaluation of capsulorhexis in femtosecond laser-assisted cataract surgery. J Cataract Refract Surg. 2013;39:1581-6.

13. Friedman NJ, Palanker DV, Schuele G, Andersen D, Marcellino G, Seibel BS, et al. Femtosecond laser capsulotomy. J Cataract Refract Surg. 2011;37:1189-98.

14. Abell RG, Kerr NM, Vote BJ. Toward zero effective phacoemulsification time using femtosecond laser pretreatment. Ophthalmology. 2013;120:942-8.

15. Hatch KM, Schultz T, Talamo JH, Dick HB. Femtosecond laser-assisted compared with standard cataract surgery for removal of advanced cataracts. Jataract Refract Surg. 2015:41:1833-8.

16. Daya SM, Nanavaty MA, Espinosa-Lagana MM. Translenticular hydrodissection, lens fragmentation, and influence on ultrasound power in femtosecond laser-assisted cataract surgery and refractive lens exchange. J Cataract Refract Surg. 2014;40:37-43.

17. Abell RG, Allen PL, Vote BJ. Anterior chamber flare after femtosecond laserassisted cataract surgery. J Cataract Refract Surg. 2013;39:1321-6.

18. Abell RG, Kerr NM, Howie AR, Mustaffa Kamal MA, Allen PL, Vote BJ. Effect of femtosecond laser-assisted cataract surgery on the corneal endothelium. J Cataract Refract Surg. 2014;40:1777-83.

19. Conrad-Hengerer I, Al Juburi M, Schultz T, Hengerer FH, Dick HB. Corneal endothelial cell loss and corneal thickness in conventional compared with femtosecond laser-assisted cataract surgery: Three-month follow-up. J Cataract Refract Surg. 2013;39:1307-13.

20. Roberts TV, Lawless M, Bali SJ, Hodge C, Sutton G. Surgical outcomes and safety of femtosecond laser cataract surgery: a prospective study of 1500 consecutive cases. Ophthalmology. 2013;120:227-33.

21. Nagy ZZ, Takacs Al, Filkorn T, Kránitz K, Gyenes A, Juhász É, et al. Complications of femtosecond laser-assisted cataract surgery. J Cataract Refract Surg. 2014:40:20-8.

22. Bali SJ, Hodge C, Lawless M, Roberts TV, Sutton G. Early experience with the femtosecond laser for cataract surgery. Ophthalmology. 2012;119:891-9.

23. Abell RG, Vote BJ. Cost-effectiveness of femtosecond laser-assisted cataract surgery versus phacoemulsification cataract surgery. Ophthalmology. 2014; 121:10-6.

24. Al Harthi K, Al Shahwan S, Al Towerki A, Banerjee PP, Behrens A, Edward DP. Comparison of the anterior capsulotomy edge created by manual capsulorhexis and 2 femtosecond laser platforms: Scanning electron microscopy study. J Cataract Refract Surg. 2014;40:2106-12.

25. Abell RG, Davies PE, Phelan D, Goemann K, McPherson ZE, Vote BJ. Anterior capsulotomy integrity after femtosecond laser-assisted cataract surgery. Ophthalmology. 2014;121:17-24.

26. Abell RG, Darian-Smith E, Kan JB, Allen PL, Ewe SY, Vote BJ. Femtosecond laser-assisted cataract surgery versus standard phacoemulsification cataract surgery: outcomes and safety in more than 4000 cases at a single center. J Cataract Refract Surg. 2015;41:47-52.

27. Conrad-Hengerer I, Hengerer FH, Joachim SC, Schultz T, Dick HB. Femtosecond laser-assisted cataract surgery in intumescent white cataracts. J Cataract Refract Surg. 2014;40:44-50.

28. Auffarth GU, Reddy KP, Ritter R, Holzer MP, Rabsilber TM. Comparison of the maximum applicable stretch force after femtosecond laser-assisted and manual anterior capsulotomy. J Cataract Refract Surg. 2013;39:105-9.

29. Jun JH, Hwang KY, Chang SD, Joo CK. Pupil-size alterations induced by photodisruption during femtosecond laser-assisted cataract surgery. J Cataract Refract Surg. 2015;41:278-85

30. Conrad-Hengerer I, Hengerer FH, Schultz T, Dick HB. Femtosecond laserassisted cataract surgery in eyes with a small pupil. J Cataract Refract Surg. 2013;39:1314-20.

31. Kerr NM, Abell RG, Vote BJ, Toh T. Intraocular pressure during femtosecond laser pretreatment of cataract. J Cataract Refract Surg. 2013;39:339-42.

32. Baig NB, Cheng GP, Lam JK, Jhanji V, Chong KK, Woo VC, et al. Intraocular pressure profiles during femtosecond laser-assisted cataract surgery. J Cataract Refract Surg. 2014;40:1784-9. 
33. Darian-Smith E, Howie AR, Abell RG, Kerr N, Allen PL, Vote BJ, et al. Intraocular pressure during femtosecond laser pretreatment: comparison of glaucomatous eyes and nonglaucomatous eyes. J Cataract Refract Surg. 2015;41:272-7.

34. Ewe SY, Oakley CL, Abell RG, Allen PL, Vote BJ. Cystoid macular edema after femtosecond laser-assisted versus phacoemulsification cataract surgery. J Cataract Refract Surg. 2015;41:2373-8.

35. Filkorn T, Kovács I, Takács Á, Horváth E, Knorz MC, Nagy ZZ. Comparison of IOL power calculation and refractive outcome after laser refractive cataract surgery with a femtosecond laser versus conventional phacoemulsification J Refract Surg. 2012;28:540-4.

36. Ewe SY, Abell RG, Oakley CL, Lim CH, Allen PL, McPherson ZE, et al. A

Comparative Cohort Study of Visual Outcomes in Femtosecond Laser-Assisted versus Phacoemulsification Cataract Surgery. Ophthalmology. 2016;123:178-82.

37. Conrad-Hengerer I, Al Sheikh M, Hengerer FH, Schultz T, Dick HB. Comparison of visual recovery and refractive stability between femtosecond laser-assisted cataract surgery and standard phacoemulsification: six-month follow-up. J Cataract Refract Surg. 2015:41:1356-64.

38. Miháltz K, Knorz MC, Alió JL, Takács Al, Kránitz K, Kovács I, et al. Internal aberrations and optical quality after femtosecond laser anterior capsulotomy in cataract surgery. J Refract Surg. 2011;27(10):711-6.

39. Chang JS, Chen IN, Chan WM, Ng JC, Chan VK, Law AK. Initial evaluation of a femtosecond laser system in cataract surgery. J Cataract Refract Surg. 2014;40:29-36

40. Mostafa YM, Mostafa HM, Salaheldin MM. Managing hard cataracts using bimanual "hole drilling" phacoemulsification. Aust J Basic Appl Sci. 2008; 2(10):1104-9.

Ready to submit your research? Choose BMC and benefit from:

- fast, convenient online submission

- thorough peer review by experienced researchers in your field

- rapid publication on acceptance

- support for research data, including large and complex data types

- gold Open Access which fosters wider collaboration and increased citations

- maximum visibility for your research: over $100 \mathrm{M}$ website views per year

At BMC, research is always in progress.

Learn more biomedcentral.com/submissions 